\title{
Refractory Extranodal Marginal Zone Lymphoma of Mucosa-Associated Lymphoid Tissue
}

National Cancer Institute

\section{Source}

National Cancer Institute. Refractory Extranodal Marginal Zone Lymphoma of Mucosa-

Associated Lymphoid Tissue. NCI Thesaurus. Code C5090.

Extranodal marginal zone lymphoma of mucosa-associated lymphoid tissue that is resistant to treatment. 